\title{
Financial support of the state for the development of animal husbandry in Kazakhstan
}

\author{
Zh. N. Sadu' ${ }^{1}$ G. M. Dyuzelbaeva ${ }^{2 \bowtie}$ \\ ${ }^{1}$ The Kazakh University of Economics, Finance and International Trade, Nur-Sultan, Republic of Kazakhstan \\ ${ }^{2}$ Kostanay Engineering and Economics University named after M. Dulatov, Kostanay, Republic of Kazakhstan \\ 区E-mail:duz_77@mail.ru
}

Annotation. Objective. The research is aimed at studying the current state of the animal husbandry industry, identifying the main problems in the animal husbandry industry and substantiating the priority areas used by the state to support agricultural producers. Methods. In the course of the research, analytical and economic-statistical methods; general scientific methods of system, comparative and structural-logical analysis were used. Results. The article presents the results of assessing the current situation in livestock farming in Kazakhstan, the dynamics of the number of livestock and poultry for 2015-2019, which affects the growth of gross livestock production, as well as the number of farm animals by region as of January - December 2019. The dynamics of the production of livestock products is analyzed as one of the priority areas for ensuring the country's food security, as well as the export, import and consumption of livestock products in the domestic market for 2015-2019. The main problems in the livestock industry are identified. The measures applied by the state to support agricultural producers through direct subsidies from local budgets are disclosed. The dynamics of subsidizing the development of livestock breeding and livestock products are presented, and the problems of the subsidy system are indicated. Identified the need to improve state support of the agroindustrial complex of Kazakhstan, the importance of state regulation of the agrarian sector of Kazakhstan to ensure the country's food security and sets out some measures of state regulation of development of agroindustrial complex. The scientific novelty of the research lies in the fact that it convincingly reveals the main problems of animal husbandry at the present stage, the directions of state financial support for agricultural producers are determined, the need to improve the issues of state support for the agro-industrial complex of Kazakhstan is substantiated.

Keywords: agro-industrial complex, agriculture, government regulation, government support, subsidies, livestock industry, livestock production, livestock breeding, livestock problems, agricultural producers.

For citation: Sadu Zh. N., Dyuzelbaeva G. M. Financial support of the state for the development of animal husbandry in Kazakhstan // Agrarian Bulletin of the Urals. 2020. No. 12 (203). Pp. 94-100. DOI: ...

Paper submitted: 16.10.2020.

\section{Introduction}

At the present stage of development of agriculture, enterprises of the agro-industrial complex (AIC) for the purpose of their sustainable development need strengthening of state regulation and financial support. Without a highly efficient agricultural sector, it is impossible to ensure sustainable development of the state, its food security, which is the basis of the society well-being. The decisive factor for the well-being of the agricultural sector is the availability of effective government regulation mechanisms. State regulation of the agroindustrial complex and rural areas, in order to ensure food security, is carried out through: the development of lending in the agro-industrial complex and rural areas; subsidizing the agro-industrial complex; implementation of mechanisms to stabilize prices for socially significant food products; purchase of agricultural products at a guaranteed purchase price; regulation of export and import of agricultural products; technical equipment, information and marketing support of the agroindustrial complex, the creation of specialized organizations; scientific, regulatory and methodological support and training for the agro-industrial complex; making investments in the development of social and engineering infrastructure in rural areas; organization of optimal rural settlement; ensuring veterinary and sanitary and phytosanitary safety; financing the costs of monitoring and assessing the reclamation state of irrigated lands; application of measures of tax, budget, customs tariff, technical regulation and other measures in accordance with the legislative acts of the Republic of Kazakhstan; monitoring, forecasting technological tasks and organizing technology transfer in the agro-industrial complex; attracting agribusiness entities to co-financing in the course of applied research and development work.

In his speech at the extensive meeting of the Government, the President of the country K.-Zh. Tokayev noted that the situation in the agro-industrial complex causes reasonable complaints; it was not possible to reveal the export potential and solve the issues of full-fledged food security of the country. It was pointed out the need for a new, verified approach in the agricultural sector, creating conditions for processing raw materials in the country, attracting investment and the latest agricultural technologies, ensuring the stability of state support measures, and improving their efficiency. 
In all countries of the world, agriculture is given priority by the state. It is in the field of agricultural products that they apply the most stringent measures to protect their market. In this regard, an effective agricultural policy, including state support, is one of the main conditions for the development of agriculture. In this regard, the issues of the need for strong state support for domestic producers, without which it is impossible to achieve the competitiveness of the agro-industrial complex and the livestock industry, in particular, are relevant.

The purpose of the study is to analyze the current state of the animal husbandry industry, identify the main problems in the industry and the priority directions used by the state to support agricultural producers.

The works of F. A. Shulenbaeva [2], Ya. V. Voronina [3], L. I. Tenkovskaya [4] are devoted to the issues of improving state support for agricultural producers. Many modern researchers have addressed the problems of state regulation of the agro-industrial complex and their importance in ensuring the country's food security: I. P. Chupina, A. G. Mokronosov [5], G. M. Dyuzelbaeva, O. I. Malyarenko [6], Ya. V. Voronina [7], A. A. Tenetko [8]. The works reveal the main conceptual approaches, methodological foundations, ways and directions of the formation of the economic mechanism of management in the agricultural sector of the economy as a whole, taking into account government intervention.

Despite the active development of these issues, not all aspects of state regulation and support for agricultural producers in general and in animal husbandry, in particular, have been studied to date, which determines the need to deepen research on this issue, taking into account modern economic conditions.

\section{Methods}

In the course of the study, analytical and economic-statistical methods, general scientific methods of systemic, comparative and structural-logical analysis were used.

\section{Results}

Agriculture of Kazakhstan, being one of the priority directions of economic development, has huge potential and large reserves. Natural conditions, their diversity determine significant potential for the development of animal husbandry. Kazakhstan traditionally engaged in sheep breeding, horse breeding, camel, cattle breeding. However, while livestock resources are used inefficiently, the competitiveness of meat products on the world market is low.

Nevertheless, Kazakhstan maintains a fairly steady growth in the development of animal husbandry. Much attention is now being paid not only to increasing the volume of production, but also to increasing the level of its efficiency and profitability. At the same time, the number of cattle in 2019 increased by $23.3 \%$ compared to 2014. In 2014, it was 6032.7 thousand heads, and in 2019 by $44.9 \%-7437.6$ thousand heads.

The business structure has changed. Earlier in the 1990s, about $70 \%$ of the livestock was in agricultural enterprises, $30 \%$ - in peasant and private farms. Currently, organized farms contain $44.9 \%$ of the cattle population.

The gross output of products (services) of the livestock industry in January-December 2019 in the country as a whole amounted to 2306.4 billion tenge, which is $4.0 \%$ higher than the level of the corresponding period of the previous year (2050.4 billion tenge). The growth in the production of livestock products is due to the increase in the slaughter of livestock and poultry in live weight by $5.5 \%$, milk yield of raw cow's milk $-3.2 \%$. Due to the number of increase in agricultural formations, there is a tendency to increase the number of cattle compared to the previous year by $4.0 \%$ to 7437.6 thousand heads, horses - by $6.8 \%$ to 2825.8 thousand heads, poultry - by $2.0 \%$ to 45.2 million heads, sheep - by $2.7 \%$ to 16.9 million heads, camels - by $3.5 \%$ to 214.8 thousand heads, pigs - by $2.9 \%$ to 822.2 thousand heads The number of goats decreased by $2.2 \%$ to 2233.7 thousand heads.

The production of commercial cow's milk increased by $2.8 \%$ to 3967.9 thousand tons, the production of hen eggs decreased by $1.1 \%$ to 5513.4 million pieces due to the technological process of changing the livestock, as well as the termination of the activity of "Tselinogradskaya Poultry Farm" LLP. In general, the main share of egg production decreased in Almaty region by 73.5 million pieces, Akmola - by 26.1 million pieces and North Kazakhstan - by 6.4 million pieces.

Production of poultry meat amounted to 222.9 thousand tons, beef -501.4 thousand tons, mutton -151.9 thousand tons.

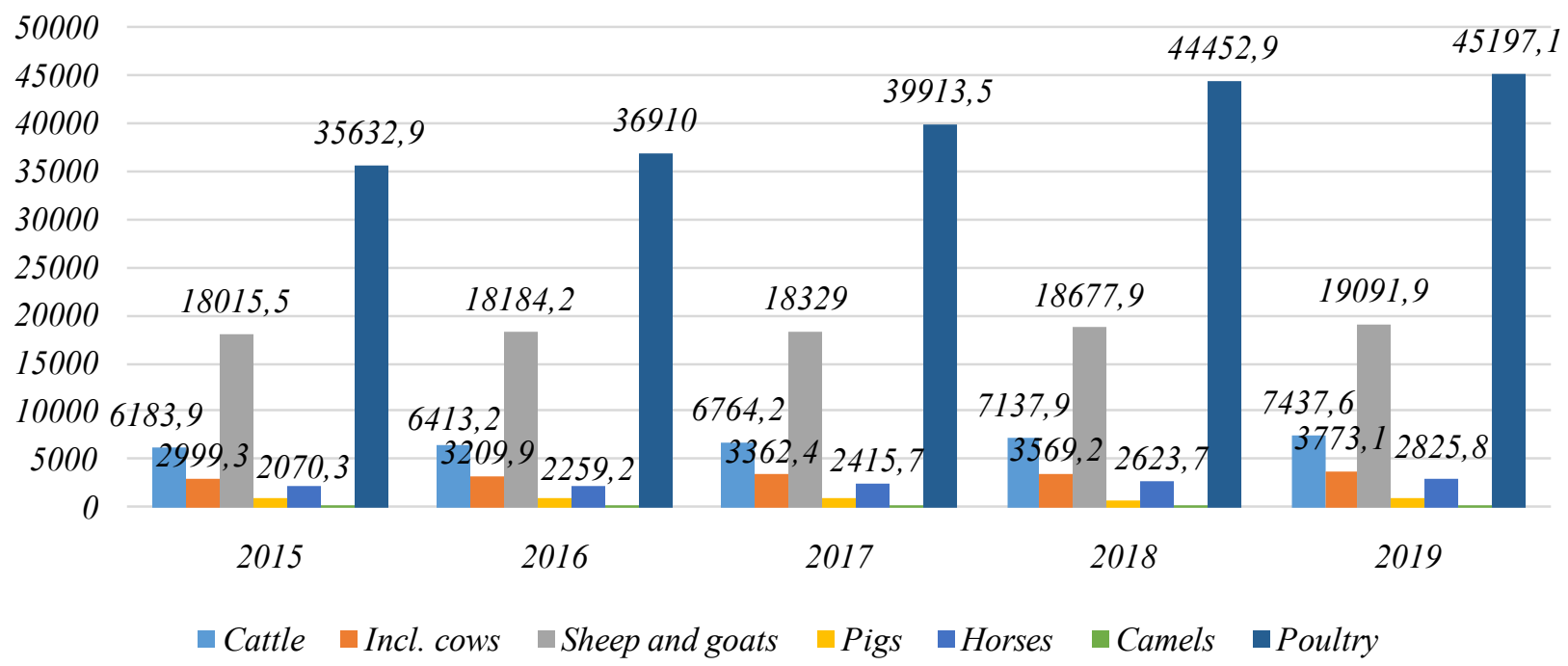

Fig. 1. Dynamics of the number of livestock and poultry in 2015-2019 (compiled by the authors based on the source [10]) 
The number of farm animals by regions as of January - December 2019*

\begin{tabular}{|l|c|c|c|c|c|c|}
\hline \multicolumn{1}{|c|}{ Name of region/city } & Cattle & Sheep/goats & Pigs & Horses & Camels & Poultry \\
\hline In the republic & 7347645 & 19091992 & 822199 & 2825851 & 214758 & 45197092 \\
\hline Akmola region & 430221 & 530206 & 101571 & 187319 & 61 & 8078887 \\
\hline Aktobe region & 493543 & 1127089 & 58417 & 144251 & 17784 & 1310547 \\
\hline Almaty region & 1027958 & 3509953 & 53563 & 326382 & 7431 & 10311125 \\
\hline Atyrau region & 173444 & 567239 & 444 & 83817 & 32448 & 455470 \\
\hline West Kazakhstan region & 591457 & 1130644 & 17271 & 192892 & 2235 & 1442759 \\
\hline Zhambyl region & 423146 & 2861844 & 20886 & 135971 & 6898 & 1701399 \\
\hline Karaganda region & 549249 & 924476 & 72223 & 337202 & 1438 & 4008831 \\
\hline Kostanay region & 462368 & 463613 & 165814 & 122881 & 247 & 4266751 \\
\hline Kyzylorda region & 332381 & 620922 & 2546 & 148339 & 47873 & 126301 \\
\hline Mangystau region & 19753 & 384385 & 45 & 74260 & 67287 & 39748 \\
\hline Pavlodar region & 426638 & 551586 & 73754 & 184591 & 95 & 1695760 \\
\hline North Kazakhstan region & 366536 & 419297 & 173988 & 131036 & 17 & 4614416 \\
\hline Turkestan region & 1052929 & 4290648 & 6561 & 346431 & 30353 & 2178513 \\
\hline East Kazakhstan region & 1004464 & 1611746 & 65271 & 394518 & 556 & 3874954 \\
\hline Nur-Sultan & 289 & 1467 & 10 & 339 & - & 72 \\
\hline Almaty & 2528 & 1495 & 276 & 792 & 35 & 5695 \\
\hline Shymkent & 80741 & 95382 & 9559 & 14830 & - & 1085864 \\
\hline
\end{tabular}

*Source: [11].

Table 2

Dynamics of production and domestic market of livestock products in 2015-2019*

\begin{tabular}{|c|c|c|c|c|c|c|c|}
\hline Year & Denomination & $\begin{array}{l}\text { Production, } \\
\text { thousand tons }\end{array}$ & $\begin{array}{c}\text { Export, } \\
\text { thousand tons }\end{array}$ & $\begin{array}{c}\text { Import, } \\
\text { thousand tons }\end{array}$ & $\begin{array}{c}\text { Domestic } \\
\text { consumption, } \\
\text { thousand tons }\end{array}$ & $\begin{array}{c}\text { Consumption } \\
1 \text { person/year, } \\
\mathrm{kg}\end{array}$ & $\begin{array}{c}\text { Import share, } \\
\%\end{array}$ \\
\hline \multirow{6}{*}{2015} & Beef & 416.8 & 1.9 & 15.4 & 450.3 & 24.4 & 3.6 \\
\hline & Mutton & 165.1 & - & - & 165.1 & 9.3 & - \\
\hline & Pork & 95.3 & 1.9 & 3.8 & 97.2 & 5.5 & 3.9 \\
\hline & Horsemeat & 101.4 & - & 3.2 & 104.6 & 5.9 & 3.1 \\
\hline & Poultry & 152.1 & 7.7 & 160.6 & 305.0 & 17.3 & 52.7 \\
\hline & Milk & 5141.6 & 16.8 & 136.8 & 5261.6 & 29.8 & 2.6 \\
\hline \multirow{6}{*}{2016} & Beef & 430.6 & 1.6 & 9.5 & 438.5 & 24.5 & 2.2 \\
\hline & Mutton & 169.2 & 0.3 & 0.1 & 169.0 & 9.4 & 0.1 \\
\hline & Pork & 93.9 & 0.8 & 1.4 & 94.5 & 5.3 & 1.5 \\
\hline & Horsemeat & 107.8 & - & 0.9 & 108.7 & 6.1 & 0.8 \\
\hline & Poultry & 152.7 & 8.8 & 165.2 & 312.0 & 17.4 & 52.9 \\
\hline & Milk & 5300.0 & 19.9 & 160.4 & 5440.5 & 30.4 & 2.9 \\
\hline \multirow{6}{*}{2017} & Beef & 450.4 & 0.9 & 15.8 & 465.3 & 25.6 & 3.4 \\
\hline & Mutton & 171.4 & 0.8 & - & 170.6 & 9.4 & - \\
\hline & Pork & 91.9 & 0.3 & 2.4 & 94.0 & 5.2 & 2.6 \\
\hline & Horsemeat & 117.5 & - & 2.6 & 120.1 & 6.6 & 2.2 \\
\hline & Poultry & 179.6 & 5.9 & 172.6 & 346.3 & 19.1 & 49.8 \\
\hline & Milk & 5460.5 & 293.6 & 159.9 & 5326.8 & 29.3 & 3.0 \\
\hline \multirow{6}{*}{2018} & Beef & 477.5 & 16.0 & 15.2 & 476.7 & 25.9 & 3.2 \\
\hline & Mutton & 170.6 & 3.8 & - & 166.8 & 9.1 & - \\
\hline & Pork & 86.2 & 1.1 & 2.0 & 87.1 & 4.7 & 2.2 \\
\hline & Horsemeat & 126.5 & - & 2.4 & 128.9 & 7.0 & 1.9 \\
\hline & Poultry & 190.8 & 8.5 & 191.7 & 374.0 & 20.3 & 51.3 \\
\hline & Milk & 5642.2 & 29.7 & 143.8 & 5756.3 & 31.1 & 2.5 \\
\hline \multirow{6}{*}{2019} & Beef & 501.4 & 5.6 & 25.8 & 521.6 & 28.0 & 4.9 \\
\hline & Mutton & 171.3 & 2.5 & 2.7 & 171.5 & 9.2 & 1.6 \\
\hline & Pork & 86.4 & 0.8 & 1.7 & 87.3 & 4.7 & 1.9 \\
\hline & Horsemeat & 131.9 & - & 2.5 & 129.4 & 7.0 & 1.9 \\
\hline & Poultry & 222.9 & 13.7 & 173.1 & 382.3 & 20.6 & 45.3 \\
\hline & Milk & 5820.1 & 39.4 & 137.1 & 538.6 & 28.9 & 2.4 \\
\hline
\end{tabular}

* Compiled by the authors based on the source [11]. 


\section{Agrarian Bulletin of the Urals No. 12 (203), 2020}

In January - December 2019, meat production in slaughter weight in all categories of farms increased by $5.8 \%$ and amounted to 1120.9 thousand tons. At the same time, in agricultural formations there is an increase in meat production by $11.4 \%$, milk by $6.2 \%$.

The average milk yield per cow remained at the level of the previous year and amounted to $2347 \mathrm{~kg}$, the average yield of eggs per 1 laying hen decreased by $2.9 \%$ against the level of the previous year and amounted to 239 pieces. At the same time, the average milk yield in agricultural enterprises per 1 cow increased by $13.5 \%$ and amounted to $4660 \mathrm{~kg}$.

Despite the increase in livestock production, domestic production of certain items does not cover even half of the population needs in the meat and dairy products.
The Ministry of agriculture imposed a ban on live cattle exports for six months due to an increase in live cattle exports in 2019 compared to 2018: 3 times or 156 thousand heads of cattle and 7 times or 263 thousand heads of small cattle. Despite the $45-50 \%$ workload of Kazakhstani meat processing plants, prices for meat products are growing. When agreeing on the ban, the National Chamber of Entrepreneurs of the Republic of Kazakhstan «Atameken» believes that in order to stabilize the internal market, resolve the issue of overflow and ensure the profitability of farmers, it is necessary to pay the difference in the form of subsidies to farmers at a high price for meat or live cattle in the markets of neighboring countries [12].

Table 3

Dynamics of subsidizing the development of livestock breeding by directions, million tenge

\begin{tabular}{|l|c|c|c|c|c|}
\hline \multicolumn{1}{|c|}{ Direction } & $\mathbf{2 0 1 5}$ year & $\mathbf{2 0 1 6}$ year & $\mathbf{2 0 1 7}$ year & $\mathbf{2 0 1 8}$ year & $\mathbf{2 0 1 9}$ year \\
\hline Meat cattle breeding & 39026.9 & 29735.2 & 22960.2 & 25127.2 & 39734.8 \\
\hline Dairy cattle breeding & 3426.3 & 3816.0 & 3412.6 & 3533.9 & 3697.6 \\
\hline Poultry & 104.4 & 250.3 & 225.2 & 490.7 & 888.0 \\
\hline Sheep breeding & 3163.6 & 4835.5 & 5072.2 & 5346.3 & 10946.7 \\
\hline Breeding stock (horses) & 254.3 & 375.8 & 224.3 & 209.3 & 154.0 \\
\hline breeding stock (camels) & 11.3 & 2.7 & 6.0 & - & 0.4 \\
\hline Breeding stock (pigs) & 1.0 & 8.0 & 1.0 & 169.9 & 447.8 \\
\hline Breeding stock (marals) & - & 2.1 & 4.8 & - & - \\
\hline breeding stock (goats) & - & - & 22.4 & - & 28.7 \\
\hline Selection and breeding work with bee colonies & 29.3 & 12.0 & 153.1 & 148.7 & 228.2 \\
\hline Selection and breeding work with marals & 43.5 & - & 99.8 & 29.8 & 9.8 \\
\hline Selection and breeding work with broodstock of pigs & - & - & - & - & 1605.3 \\
\hline Keeping sheep in a commercial flock & - & - & - & 37.3 & 106.0 \\
\hline Keeping bulls of producers & 335.6 & 381.5 & 330.2 & 692.3 & 1674.7 \\
\hline Bull Seed & - & - & - & 30.0 & 267.4 \\
\hline Total & 31187.4 & 39419.1 & 32512.2 & 35815.2 & 59797.8 \\
\hline$\%$ of the total allocated funds & 45.2 & 46.9 & 48.0 & 46.7 & 51.7 \\
\hline
\end{tabular}

* Source [11].

Table 4

Dynamics of subsidies for manufactured products by type, million tenge*

\begin{tabular}{|l|c|c|c|c|c|}
\hline \multicolumn{1}{|c|}{ Denomination } & 2015 year & 2016 year & 2017 year & 2018 year & 2019 year \\
\hline Fattening bulls & 4533.9 & 7992.0 & 4240.9 & 6158.2 & 5274.4 \\
\hline Pork & 2925.2 & 3508.0 & 2972.9 & 1584.8 & 199.0 \\
\hline Lamb (lamb) & 467.7 & 840.3 & 76.5 & 237.9 & 514.9 \\
\hline Horsemeat & 386.4 & 497.6 & 441.5 & 581.6 & - \\
\hline Koumiss & 302.9 & 401.0 & 559.1 & 635.9 & 1070.8 \\
\hline Shubat & 177.3 & 193.9 & 218.0 & 227.1 & 297.8 \\
\hline Camel meat & 37.2 & 36.5 & 11.1 & 3.5 & - \\
\hline Wool (thin, semi-fine) & 211.7 & 238.2 & 260.7 & 282.6 & 257.6 \\
\hline Poultry (turkey, waterfowl & 7888.2 & 9058.3 & 7833.7 & 8634.8 & 15838.4 \\
\hline Marketable egg (quail) & 8884.3 & 9753.5 & 7096.2 & 8009.5 & 10877.7 \\
\hline Cow's milk & 5056.7 & 6402.4 & 6703.2 & 8307.9 & 11231.5 \\
\hline Juicy and roughage & 6671.7 & 5132.3 & 4838.8 & 4953.1 & 4218.4 \\
\hline Goat milk & - & - & 17.7 & 7.1 & - \\
\hline Sale of bulls to feedlots & 330.1 & 591.1 & - & 1212.4 & 6045.6 \\
\hline Total & 37873.6 & 44645.1 & 35270.4 & 40836.4 & 55826.1 \\
\hline \% of the total allocated funds & 55.0 & 53.1 & 52.0 & 53.3 & 48.3 \\
\hline$*$ Source [11) & & & & & \\
\hline
\end{tabular}


It should be noted that in Kazakhstan about $40 \%$ of livestock belongs to private farmsteads and households, which are not always able to provide livestock with the necessary conditions and most of them do not have the opportunity to equip their farms with the appropriate technical equipment, which in turn has a significant impact on the quality of products. For example, in the Republic of Belarus almost $100 \%$ of livestock is kept in large organized dairy farms, in the Russian Federation - more than $50 \%$.

Due to the fact that part of the livestock is concentrated in households, the livestock industry is characterized by such characteristics as low genetic potential of animals and associated low productivity, lack of use of modern technologies for keeping, feeding and other technologies that ensure productivity and quality of products, insufficient care for the health of animals.

The quality of the feed base has a great influence on the productivity of animal husbandry. In order to obtain meat and dairy products of good quality, in addition to the appropriate conditions, it is necessary to own a large-scale and high-quality feed base. Most of the existing pastures do not require the presence of water bodies due to their location, which also reduces the possibility of keeping livestock. The issue of importing cattle from abroad also requires attention. It is necessary to pay attention to compliance with local climatic conditions, modern detection and exclusion of the import of sick animals, etc. [13, p. 29].

In order to encourage an increase in the number of breeding stock, increase the proportion of breeding animals to the total number, as well as the volume of livestock production, improve its quality and competitiveness, the state is taking measures to support agricultural producers through direct subsidies to them from local budgets in two directions:

1) development of livestock breeding;

2) production of livestock products.

Subsidizing these areas is carried out within the framework of the Rules for subsidizing the development of livestock breeding, increasing the productivity and quality of livestock products [14].

The volume of state support for agriculture of the Republic of Kazakhstan is increasing annually. Over the past five years, the volume of subsidies has doubled and in 2019 amounted to 115.6 billion tenge (for comparison, in 2015 - 69.0 billion tenge).

Subsidies for the development of livestock breeding are intended for:

- partial reduction in price (up to $50 \%$ ) of the cost of pedigree young cattle, sheep, goats, stallions, pigs, camels and day-old chickens purchased by domestic producers;

- reducing the cost of breeding and breeding work with breeding stock of cattle, sheep, pigs, marals (deer), as well as bee colonies;

- cheaper costs of individuals and legal entities for the maintenance of breeding bulls-producers of meat and dairymeat breeds used for the reproduction of a commercial and public herd, sheep for the reproduction of a commercial flock;

- reduction in the cost of the purchased unisexual and bisexual semen of a breeding bull of dairy and dairy-meat breeds;

- subsidizing services for embryo transplantation;
- reimbursement of the costs of breeding and distribution centers for the provision of services for the artificial insemination of the breeding stock of cattle and sheep in agricultural cooperatives, as well as in peasant (farm) farms [11, p.67].

Subsidizing the increase in productivity and quality of livestock products is aimed at:

- cheaper cost of bulls sold for feeding in feedlots with a capacity of at least 1000 heads at a time;

- reducing the cost of fattening bulls for feedlots with a capacity of at least 1000 heads at a time;

- cheaper cost of the lambs sold;

- reduction in the cost of production of milk (cow, mare, camel), poultry (broiler meat, turkey, waterfowl), edible eggs (chicken eggs), thin and semi-thin wool;

- reduction in the cost of feed costs for dairy cattle [11, p. 68].

At the same time, within the framework of the state program for the development of the agro-industrial complex, in order to increase the availability of financing for agribusiness entities, it is planned to gradually reduce ineffective subsidies, which directly distort pricing and are referred to the "yellow" basket according to the WTO methodology. Such market-distorting type of subsidies includes commodity-specific subsidies (per unit of output) [15].

The released subsidies will be directed to effective financial instruments, such as: the development of livestock breeding, subsidizing the interest rate on loans, leasing of agricultural machinery and animals, investment subsidies, subsidizing insurance premiums, developing a system of credit partnerships and loan guarantee institutions.

It should be noted that the current system of subsidies is not effective enough, it does not provide for the achievement of specific predetermined results, the mandatory introduction of effective technologies, etc. Recent years have been characterized by instability in the types and conditions of subsidies, and its final criteria have not been worked out. According to NCE "Atameken", over the past 5 years, the subsidy rules have changed 47 times [12]. All this causes discontent among agricultural producers.

On the other hand, agricultural producers have developed a habit of relying only on budget subsidies. Such subsidies should be directed to the priority areas of the agro-industrial complex related to ensuring the country's food security, where one cannot do without state support, which in turn will ensure the stability of the subsidy rules. Specific performance indicators should be identified, both for the recipients of subsidies and for the agro-industrial complex as a whole, for the achievement of which both the heads of the relevant state bodies and the recipients of subsidies should be directly responsible. At the same time, the basis for further government support should be the achievement of positive trends in the agricultural sector, and not the rapid development of subsidies.

The Ministry of Agriculture identified 15 priority areas for the development of exports and import substitution of agricultural products. Beef cattle breeding and sheep breeding represent a great potential for the development of the industries (the potential for an increase is 2,616 million US dollars). Family farms will form the basis of the National Strategy: in cattle breeding there are 50-100 queen heads, in sheep breeding - 
600 queen heads, and not large-scale production. Foreign experience shows that in Australia, Canada and the United States the main share in the production cycle is taken by small farms with an average livestock of 50 heads, they are competitive in terms of cost due to simple animal husbandry technology, low production costs and are more resistant to market changes. There will be 100 thousand such farmers created within the framework of the Program for the Development of Meat Livestock for 2018-2027. More than 500 thousand jobs will be created in rural areas. Labor productivity per employee per year will increase to USD 8,000 thousand. The multiplier effect of the Program is the development of local content (mechanical engineering, irrigation, alternative sources of energy supply). The main advantages for the implementation of the Program are the availability of sufficient areas of pastures, irrigated land and the traditional nature of the livestock industry, as well as the proximity of such strategic markets with stable imports of beef and lamb, such as the countries of the Middle East and East Asia (China, Iran, Saudi Arabia, Vietnam) [16].

\section{Discussion and Conclusion}

The obtained results of the study of the processes occurring in the animal husbandry industry make it possible to formulate the following main problems: small-scale production, low productivity of farm animals, underdevelopment of the fodder industry, lack of free land for animal husbandry, lack of qualified personnel, scientific research, lack of stable sales markets, weak competitiveness, and problems of veterinary medicine.

Currently, state support for the agro-industrial complex is mainly carried out by: 1) budget lending or participation in the formation or increase of the authorized capital of specialized organizations; 2) subsidies, which should be carried out under conditions of economic efficiency of subsidies and improving the quality and competitiveness of products.

At the same time, the achievement of positive trends in the agricultural sector should serve as the basis for further state support.

\section{References}

1. Tokaev K.-Zh. Vystuplenie na rasshirennom zasedanii Pravitel'stva Respubliki Kazakhstan 24 yanvarya 2020 goda [Speech at an expanded meeting of the Government of the Republic of Kazakhstan on January 24, 2020] [e-resource]. URL: https:// www.akorda.kz/ru/speeches/internal_political_affairs/in_speeches_and_addresses/vystuplenie-prezidenta-kasym-zhomartatokaeva (appeal date: 19.08.2020). (In Russian.)

2. Shulenbaeva F. A. Problemy i perspektivy razvitiya otrasli zhivotnovodstva // Problemy Agrorynka. 2018. No. 2. Pp. 155161. (In Russian.)

3. Voronina Ya. V. Gosudarstvennoe regulirovanie i gosudarstvennaya podderzhka fermerskikh khozyaystv // Agrarian Bulletin of the Urals. 2016. No. 9 (151). Pp. 103-110. (In Russian.)

4. Ten'kovskaya L. I. Mekhanizmy razvitiya i gosudarstvennoy podderzhki sel'skogo khozyaystva // Agrarian Bulletin of the Urals. 2016. No. 03 (145). Pp. 109-112. (In Russian.)

5. Chupina I. P., Mokronosov A. G. Sistemnyy kharakter prodovol'stvennoy bezopasnosti Rossii // Agrarian Bulletin of the Urals. 2016. No. 05 (147). Pp. 118-122. (In Russian.)

6. Dyuzelbayeva G., Malyarenko O. The role of state regulation in the development of the agro-industrial complex of the region (Kostanay region) // Agrarian Bulletin of the Urals. 2020. No. 02 (193). Pp. 70-77.

7. Voronina Ya. V. Neobkhodimost' organizatsionno-ekonomicheskikh mekhanizmov gosudarstvennogo regulirovaniya agrarnoy sfery ekonomiki i razvitiya fermerskikh khozyaystv // Agrarian Bulletin of the Urals. 2017. No. 12-2 (167). Pp. 24-31. (In Russian.)

8. Tenetko A. A. Sostoyanie i problemy gosudarstvennogo regulirovaniya agrarnogo sektora Rossiyskoy Federatsii [Condition and problems of state regulation of the agrarian sector of the Russian Federation] // Agrarian Bulletin of the Urals. 2016. No. 12 (154). Pp. 89-95. (In Russian.)

9. Esymkhanova Z. K., Sadu Zh. N. Tendentsii regulirovaniya sfery APK Kazakhstana v usloviyakh resursosberezheniya [Trends in the regulation of the agro-industrial complex of Kazakhstan in the context of resource conservation] // Bulletin of the Kazakh University of Economics, Finance and International Trade. 2020. No. 1 (38). Pp. 56-65. (In Russian.)

10. Statisticheskie dannye Komiteta po statistike MNE RK [Statistical data of the Committee on Statistics of the Ministry of National Economy of the Republic of Kazakhstan] [e-resource]. URL: http://stat.gov.kz/faces/homePage (appeal date: 17.07.2020). (In Russian.)

11. Parlamentskie slushaniya na temu "Voprosy razvitiya agropromyshlennogo kompleksa". Senat Parlamenta Respubliki Kazakhstan. Komitet po agrarnym voprosam, prirodopol'zovaniyu i razvitiyu sel'skikh territoriy [Parliamentary hearings on the topic "Issues of the development of the agro-industrial complex". Senate of the Parliament of the Republic of Kazakhstan. Committee on Agrarian Issues, Nature Management and Rural Development]. Nur-Sultan, 28 February, 2020.84 p. (In Russian.)

12. Zhumagaziev E. Zapret na eksport KRS: "Takaya korova nuzhna samomu”! [Ban on the export of cattle: "You need such a cow yourself!'] [e-resource]. URL: https://atameken.kz/ru/news/34510-zapret-na-eksport-krs-takaya-korova-nuzhna-samomu (appeal date: 21.07.2020). (In Russian.)

13. Informatsionno-analiticheskiy obzor k parlamentskim slushaniyam na temu "Voprosy razvitiya agropromyshlennogo kompleksa" [Information and analytical review for the parliamentary hearings on the topic "Issues of the development of the agroindustrial complex"]. Nur-Sultan: Senate apparatus. Information and analytical department, 2020. 55 p. (In Russian.) 
14. Pravila subsidirovaniya razvitiya plemennogo zhivotnovodstva, povysheniya produktivnosti i kachestva produktsii zhivotnovodstva. Utverzhdennye prikazom Ministra sel’skogo khozyaystva RK ot 15 marta 2019 goda № 108 [Rules for subsidizing the development of livestock breeding, increasing the productivity and quality of livestock products. Approved by the order of the Minister of Agriculture of the Republic of Kazakhstan dated March 15, 2019 No. 108] [e-resource]. URL: http://adilet.zan. kz/rus/docs/V1900018404 (appeal date: 21.07.2020). (In Russian.)

15. Gosudarstvennaya programma razvitiya agropromyshlennogo kompleksa Respubliki Kazakhstan na 2017-2021 gody. Ukaz Prezidenta Respubliki Kazakhstan ot 14.02.2017 goda № 420 (s izm. i dop. ot 12 iyulya 2018 goda № 423) [State program for the development of the agro-industrial complex of the Republic of Kazakhstan for 2017-2021. Decree of the President of the Republic of Kazakhstan dated February 14, 2017 No. 420 (with amendments and additions dated July 12, 2018 No. 423)] [e-resource]. URL: https://primeminister.kz/ru/gosprogrammy/gosudarstvennaya-programma-razvitiya-agropromyshlennogokompleksa-rk-na-2017-2021-gody (appeal date: 21.07.2020). (In Russian.)

16. Programma razvitiya myasnogo zhivotnovodstva na 2018-2027 gody [Program for the development of beef cattle breeding for 2018-2027] [e-resource]. URL: https://meatunion.kz/images/nacionalnayaprogramma.pdf (appeal date: 21.07.2020). (In Russian.)

\section{Authors' information:}

Zhanna N. Sadu ${ }^{1}$, candidate of economic sciences, senior lecturer, ORCID 0000-0001-8060-8056;

+7707903-20-77,sdm_2008@mail.ru

Gulnara M. Dyuzelbaeva ${ }^{2}$, candidate of economic sciences, assistant professor, ORCID 0000-0002-7782-8469; +7701343-33-04,duz77@mail.ru

${ }^{1}$ The Kazakh University of Economics, Finance and International Trade, Nur-Sultan, Republic of Kazakhstan

${ }^{2}$ Kostanay Engineering and Economics University named after M. Dulatov, Kostanay, Republic of Kazakhstan 